liubapetyk@ukr.net).

БАЦМАН Ірина Вікторівна - студентка факультету управління фінансами та бізнесу, Львівський національний університет імені Івана Франка (79000, м. Львів, вул. Медової Печери, 53, e-mail: ira.batsman@ukr.net).

БІДА Марта Сергіївна - студентка факультету управління фінансами та бізнесу, Львівський національний університет імені Івана Франка (79000, м. Львів, вул. Медової Печери, 53, e-mail: mybonanzaluck @gmail.com).

PETYK Lyubov - Candidate of Economic Sciences, Associate Professor of the Department of Financial Management, Ivan Franko National University of Lviv (79000, Lviv, 53, Medova Pechera Str., e-mail: liubapetyk@ukr.net).

BATSMAN Iryna - Student of the Faculty of Financial Management and Business, Ivan Franko National University of Lviv (79000, Lviv, 53, Medova Pechera Str., e-mail: ira.batsman@ukr.net).

BIDA Marta - Student of the Faculty of Financial Management and Business, Ivan Franko National University of Lviv (79000, Lviv, 53, Medova Pechera Str., e-mail: mybonanzaluck@gmail.com).

ПЕТИК Любовь Орестовна - кандидат экономических наук, доцент кафедры финансового менеджмента, Львовский национальный университет имени Ивана Франка (79000, г. Львов, ул. Медовой Пещеры, 53, e-mail: liubapetyk@ukr.net).

БАЦМАН Ирина Викторовна - студентка факультета управления финансами и бизнеса, Львовский национальный университет имени Ивана Франка (79000, г. Львов, ул. Медовой Пещеры, 53, e-mail: ira.batsman@ukr.net).

БИДА Марта Сергеевна - студентка факультета управления финансами и бизнеса, Львовский национальный университет имени Ивана Франка (79000, г. Львов, ул. Медовой Пещеры, 53, e-mail: mybonanzaluck@ gmail.com).

УДК: 332.12:338.43:339.92

DOI: 10.37128/2411-4413-2021-4-8

ТОМАШУК І.В., доктор філософії з економіки, стариий викладач кафедри економіки та підприємницької діяльності

РОЗВИТОК

СІЛЬСЬКИХ

ТЕРИТОРІЙ

УКРАЇНИ В

СИСТЕМI

СВРОІНТЕГРАЦІЙНИХ ПРОЦЕСІВ
БАЛДИНЮК В.М., кандидат наук з держсавного управління, доцент кафедри адміністративного менеджсменту та альтернативних джсерел енергї, Вінницький національний аграрний університет (м. Вінниця)

ТОМАШУК І.О., аспірант Національного наукового центру "Інститут аграрної економіки" (м. Kü̈в) 
У статті означено, щзо сучасний глобальний економічний простір сприяє інтеграції між країнами як в економічному, так і політичному сенсі, змічненню торгівельних зв'язків, коопераиіï та співпраці між краӥнами. Сталий економічний розвиток $\epsilon$ об'єктивною необхідністю подальшого розвитку виробничих відносин у світі. Наголошено на потребі посилення торговельних відносин між Україною та ЄС на основі Угоди про поглиблену й всеохопну зону вільної торгівлі, щзо є розділом Угоди про Асочіачію між Україною та ЄС. Зазначено, щзо однією із причин кризового стану сільських територій Украӥни $\epsilon$ монофункціональний характер розвитку сільської економіки, основою якої залишається сільське господарство. Обтрунтовано, щзо важливим напрямком політики розвитку сільських територій в Україні є державна підтримка формування, нагромадження та використання людського капіталу села. Встановлено, що вирімальний вплив на розвиток сільських територій кожного макро- чи мікрорегіону має їх ресурсний потенціал. Наголошено, щуо диверсифікація сільської економіки повинна базуватися на використанні внутрішнього потенціалу, зокрема, на розвитку дрібних і середніх підприємств. Зазначено, що сьогодні на порядку денному в СС стоять питання зміни клімату, ефективного використання ресурсів $i$ територіального балансу. СС перебуває на етапі пошуку найбільш ефективних та далекоглядних иляхів виходу 3 кризи, орієнтуючись на побудову більш конкурентоспроможної економіки з високим рівнем зайнятості. Запропоновано розробити комплекс регіональних програм розвитку сільських територій Украӥни; зосередити державну політику на розвитку людського капіталу як основи функціонування села; забезпечити відповідну інституційну структуру, здатну здійснювати безперервний моніторинг стану сільських територій та сприяти обміну досвідом із країнами Свропи й іншими розвиненими краӥнами світу.

Ключові слова: сільські території, сталий розвиток, глобалізація, інтеграція, реструктуризація, децентралізація, інновації, євроінтеграція.

Табл.: 3. Рис.: 3. Літ.: 21.

\title{
DEVELOPMENT OF RURAL TERRITORIES OF UKRAINE IN THE SYSTEM OF EUROPEAN INTEGRATION PROCESSES
}

\author{
TOMASHUK Inna, \\ PhD of Economics, Senior Lecturer \\ of the Department of Enterprise and Economics
}

\begin{abstract}
BALDYNYUK Vasyl, Candidate of Science in Public Administration, Associate Professor of the Department of Administrative Management and Alternative Energy Sources, Vinnytsia National Agrarian University (Vinnytsia)

\section{TOMASHUK Ivan, Postgraduate Student of the National Research Center "Institute of Agrarian Economics»} (Kyiv)

The article states that the modern global economic space promotes integration between countries in both economic and political sense, strengthening the trade ties, cooperation and partnership between countries. Sustainable economic development is an objective necessity for the further development of production relations in the world. Authors emphasize there is a need to 
deepen trade relations between Ukraine and the EU on the basis of the Deep and Comprehensive Free Trade Agreement, which is a section of the Association Agreement between Ukraine and the EU. It is noted that one of the reasons of the crisis in rural areas of Ukraine is the nonfunctional nature of rural development, the basis of which is agriculture. It is substantiated that important direction of rural development policy in Ukraine is the state support for the formation, accumulation and use of human capital in rural areas. It is emphasized that the decisive influence on the development of rural areas of each macro- or micro-region has available resource potential. It was emphasized that the diversification of the rural economy should be based on the use of domestic potential, in particular, on the development of small and medium enterprises. It is noted that the issues of climate change, efficient use of resources and territorial balance are on the agenda in the EU today. The EU is in the process of finding the most effective and far-sighted ways out of the crisis, focusing on building a more competitive economy with a high level of employment. It is proposed to develop a set of regional programs for the development of rural areas of Ukraine; to focus public policy on the development of human capital as the basis for the functioning of the village; to provide an appropriate institutional structure capable of continuous monitoring of the state of rural areas and facilitate the exchange of experiences with European countries and other developed countries.

Key words: rural areas, sustainable development, globalization, integration, restructuring, decentralization, innovation, European integration.

Tab.: 3. Fig.: 3. Ref.: 21.

\title{
РАЗВИТИЕ СЕЛЬСКИХ ТЕРРИТОРИЙ УКРАИНЫ В СИСТЕМЕ ЕВРОИНТЕГРАЦИОННЫХ ПРОЦЕССОВ
}

ТОМАШУК И.В., доктор философии по экономике, старший преподаватель кафедры экономики и предпринимательской деятельности

\author{
БАЛДИНЮК В.М., \\ кандидат наук по государственному управлению, доцент кафедры \\ админитративного менеджмента \\ и альтернативных источников энергии,
} Винницкий национальный аграрный университет (2. Винница) ТОМАШУК И.А.
аспирант Национального научного центра
«Иститут аграрной экономики» (2. Киев)

В статье указано, что современное глобальное экономическое пространство способствует интеграции между странами как в экономическом, так и политическом смысле, укреплению торговых связей, кооперачии и сотрудничества между странами. Устойчивое экономическое развитие является объективной необходимостью дальнейшего развития производственных отночений в мире. Акиентируется внимание на углублении торговых отнотений между Украиной и EC на основе Соглашения о углубленной $u$ всеобъемлющей зоне свободной торговли, что является разделом Соглашения об Ассочиации между Украиной и ЕС. Указано, что одной из причин кризисного состояния сельских 
территорий Украины является монофункииональный характер развития сельской экономики, основой которой остается сельское хозяйство. Обосновано, что важным направлением политики развития сельских территорий в Украине является государственная поддержка формирования, накопления и использования человеческого капитала села. Установлено, что решающее влияние на развитие сельских территорий каждого макро- или микрорегиона имеет их ресурсный потенциал. Исследовано, что диверсификаџия сельской экономики должна базироваться на использовании внутреннего потенциала, в частности, развития мелких и средних предприятий. Сделаны выводы, что сегодня на повестке дня в ЕС стоят вопросы изменения климата, эффективного использования ресурсов и территориального баланса. ЕС находится на этапе поиска наиболее эффективных и дальновидных путей выхода из кризиса, ориентируясь на построение более конкурентоспособной экономики с высоким уровнем занятости. Предложено разработать комплекс региональных программ развития сельских территорий Украины; сосредоточить государственную политику на развитии человеческого капитала, как основы функционирования села, обеспечить соответствуюшую институциональную структуру, способную осуществлять непрерывный мониторинг состояния сельских территорий и способствовать обмену опытом со странами Европь и другими развитыми странами мира.

Ключевые слова: сельские территории, устойчивое развитие, глобализация, интеграция, реструктуризация, децентрализация, инновации, евроинтеграция.

Табл.: 3. Рис.: 3. Лит.: 21.

Постановка проблеми. Одним із важливих завдань економічної політики України $є$ перехід на шлях сталого розвитку. Реалізацію цього завдання держава може здійснити за допомогою раціонального й ефективного використання ресурсного потенціалу підприємств, зокрема сільськогосподарських, а також реструктуризації виробництва й використання трудового потенціалу.

Сучасний стан сільських територій України характеризується не лише значними структурними, функціональними й пов'язаними 3 ними демографічними проблемами, але також відзначається значним потенціалом до розвитку сільськогосподарської та інших видів підприємницької діяльності на селі.

Незважаючи на перші значні кроки у реалізації заходів щодо розвитку сільських територій в Україні, важливе подальше вдосконалення цих механізмів, що передбачає вивчення та впровадження кращих світових практик, серед яких досвід країн $\mathrm{EC}$, де діє ефективний механізм розвитку сільських територій, який охоплює низку заходів для подолання соціально-економічних проблем села.

Аналіз останніх досліджень і публікацій. Проблеми розвитку сільських територій тривалий час вивчаються українськими вченими-економістами, серед яких Калетнік Г.М. [11], Гончарук І.В. 5; 6; 11], Браніцький Ю.Ю. [5], Борщевський В.В. [1], Мазур К.В. [13], Важинський Ф.А. [2], Венгерська Н.С. [3; 4], Гилка М.Д. [7], Ковальчук С.Я. [12], Піняга Н.О. [16], Чеканська Л.А. [20], Яценко О.М. [21], Невзгляд Н.Г. [21], Невзгляд. А.Г. [21] та інші. У їхніх працях відображені грунтовні результати досліджень засад багатофункціонального розвитку села, сільських територій та сільського 
простору; принципів соціально-економічного управління розвитком сільських територій; стратегічних аспектів розвитку соціопросторових аграрних систем, а також аналізується досвід розвитку сільських територій у зарубіжних країнах. Однак, занепад сільських територій України й низка тісно пов'язаних демографічних i соціальних проблем вимагають продовження досліджень різних аспектів цієї проблематики в контексті необхідності реалізації концепції гармонійного розвитку й активізації ролі держави щодо підтримки нею процесів посилення рівня зрівноваженості зазначеного розвитку.

Формулювання цілей статті. Метою статті $є$ дослідження основних засад формування сталого розвитку сільських територій в Україні 3 врахуванням досвіду такого розвитку в зарубіжних країнах і можливістю запровадження його в українських реаліях в умовах євроінтеграції.

Виклад основного матеріалу дослідження. Розвиток європейської інтеграції сприяє змінам у сільському господарстві й розвитку порівняно нового напряму досліджень української аграрної науки. Європейські орієнтири української економіки надають аграрному сектору відповідний вектор розвитку й відкривають нові можливості для розвитку сільськогосподарського виробництва, створюють додаткові переваги на агропродовольчому ринку. Серйозним кроком із позиції поглиблення торговельних відносин між Україною та СС має стати Угода про поглиблену й всеохопну зону вільної торгівлі між Україною та СС, яка сприятиме наближенню вітчизняного аграрного сектора економіки до європейських стандартів, адаптації його до Спільної аграрної політики $Є \mathrm{C}$ i розширенню присутності на українському агропродовольчому ринку продукції нових країн-членів EC [10].

Свропейська політика сільського розвитку еволюціонувала як частина розвитку Спільної аграрної політики - з політики, яка стосувалася структурних проблем сільськогосподарського сектору, до політики, зорієнтованої на багатофункціональність ведення сільського господарства $[1$, с. 7 ; 6, с. 20]. Основними цілями Спільної аграрної політики $є$ такі: підвищення продуктивності сільськогосподарського виробництва через стимулювання технічного прогресу, забезпечення раціонального розвитку аграрного виробництва й оптимального використання факторів виробництва, a саме: праці, забезпечення справедливих стандартів життя сільського населення за допомогою збільшення доходів осіб, які зайняті у сільському господарстві, стабілізація ринків, забезпечення продовольчої безпеки, забезпечення формування прийнятної для споживачів цінової політики $[1$, c. 8$]$.

Досягнення поставлених цілей забезпечується визначенням базових принципів функціонування Спільної аграрної політики, до яких належать: вільний рух товарів усередині $€ \mathrm{C}$ і спільні ціни для однакових товарів, спільність переваг, що передбачало надання пріоритетності товарам, 
виробленим на внутрішньому ринку, над імпортованою продукцією, а також спільна фінансова відповідальність за ринкову й цінову політику СС (рис. 1).

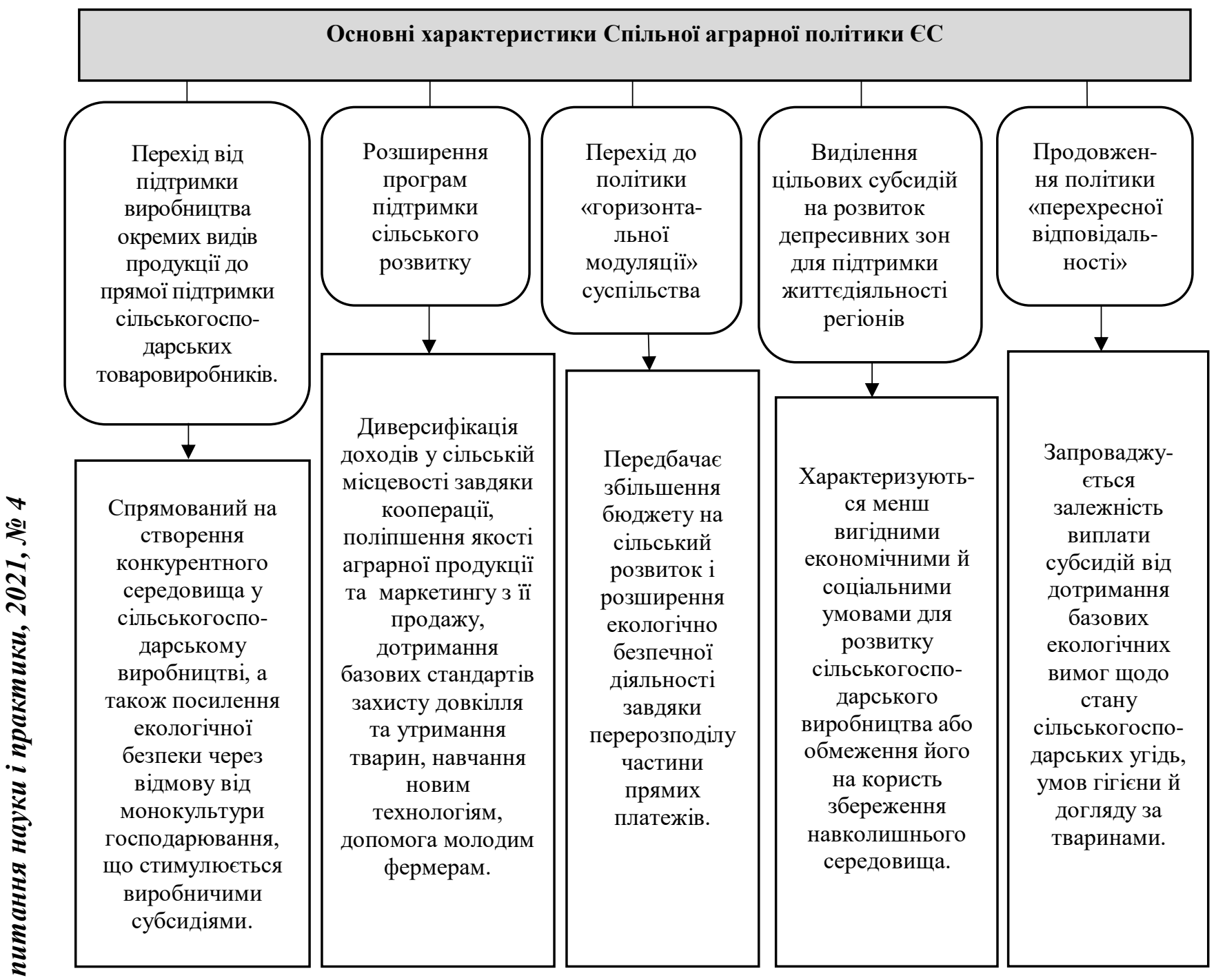

\section{Рис. 1. Основні характеристики Спільної аграрної політики $\mathbf{C C}$ Джерело: [4, с. 96; 12, с. 55]}

Нині існує 118 різних Програм розвитку сільських територій (RDP) у державах-членах Свропейського Союзу, а також 20 окремих національних програм. 8 держав-членів ЄС бажають мати дві або більше (регіональних) Програм розвитку сільських територій [17]. Такі показники відображають важливість розвитку сільських територій для країн-членів ЄС. Разом із тим, сучасна Спільна аграрна політика ЄС (2014-2020рр.) порівняно 3 попереднім періодом (2008-2013 рр.) має відмінні риси та характеристики.

Науковці ННЦ «Інститут аграрної економіки» України розробили Стратегічні напрями сталого розвитку сільських територій України на період до 2030 року. Ці напрями охоплюють практично всі сфери аграрного сектору економіки України:

- удосконалення управління сталим розвитком сільських територій;

- формування оптимальної сільської поселенської мережі й покращення 
відтворюваності людності;

- соціальний захист сільського населення;

- поліпшення житлових умов;

- розвиток транспортної інфраструктури;

- доступність загальної освіти у селі;

- забезпечення сільських жителів якісною медичною допомогою;

- забезпечення зайнятості й підвищення рівня життя сільського населення;

- диверсифікація сільської економіки;

- розвиток підприємництва й малих форм господарювання у сільській місцевості;

- розвиток сільського туризму й рекреаційної сфери у селі;

- розвиток сільськогосподарської обслуговуючої кооперації;

- раціональне використання природно-ресурсного потенціалу сільських територій;

- техногенна й екологічна безпека сільських територій;

- фінансове забезпечення сталого розвитку сільських територій;

- матеріально-технічне забезпечення сталого розвитку сільських територій;

- інвестиційне та інноваційне забезпечення сталого розвитку сільських територій;

- розвиток сільськогосподарської інформаційно-консультативної діяльності.

Основою наведених вище Стратегічних напрямів сталого розвитку сільських територій України на період до 2030 року $€$ системний та фундаментальний підхід. Важливим чинником успішної реалізації Стратегічних напрямів $є$ формування моніторингу сталого розвитку сільських територій та запровадження у практику управління ефективних механізмів прогнозування та контролю на різних рівнях управління розвитком [14]. На рис. 2 представлено основні характеристики сільського розвитку в контексті Стратегії «Свропа 2020».

Важливу роль у розвитку країни й реалізації ï потенціалу відіграють зовнішньоекономічний вектор, особливості зовнішньої політики, міжнародні торгові партнери й активність взаємодії 3 ними. Сучасний глобальний економічний простір сприяє інтеграції між країнами як в економічному, так і в політичному сенсі, зміцненню торгових зв'язків, співпраці й кооперації між ними. Ті країни, які залишаються поза цими процесами, не можуть залишатися конкурентоспроможними в довгостроковій перспективі, особливо у випадку невикористаного внутрішнього економічного потенціалу або неефективного його використання. Економічна інтеграція 3 таким об'єднанням країн, як Європейський Союз, несе в собі значно більший позитивний потенціал, аніж негативний. Економіка країн $\mathrm{CC}$, у своїй переважній більшості, функціонує на конкурентних засадах, прагненні підприємств до максимізації конкурентоспроможності, лідерства на основі якості. 


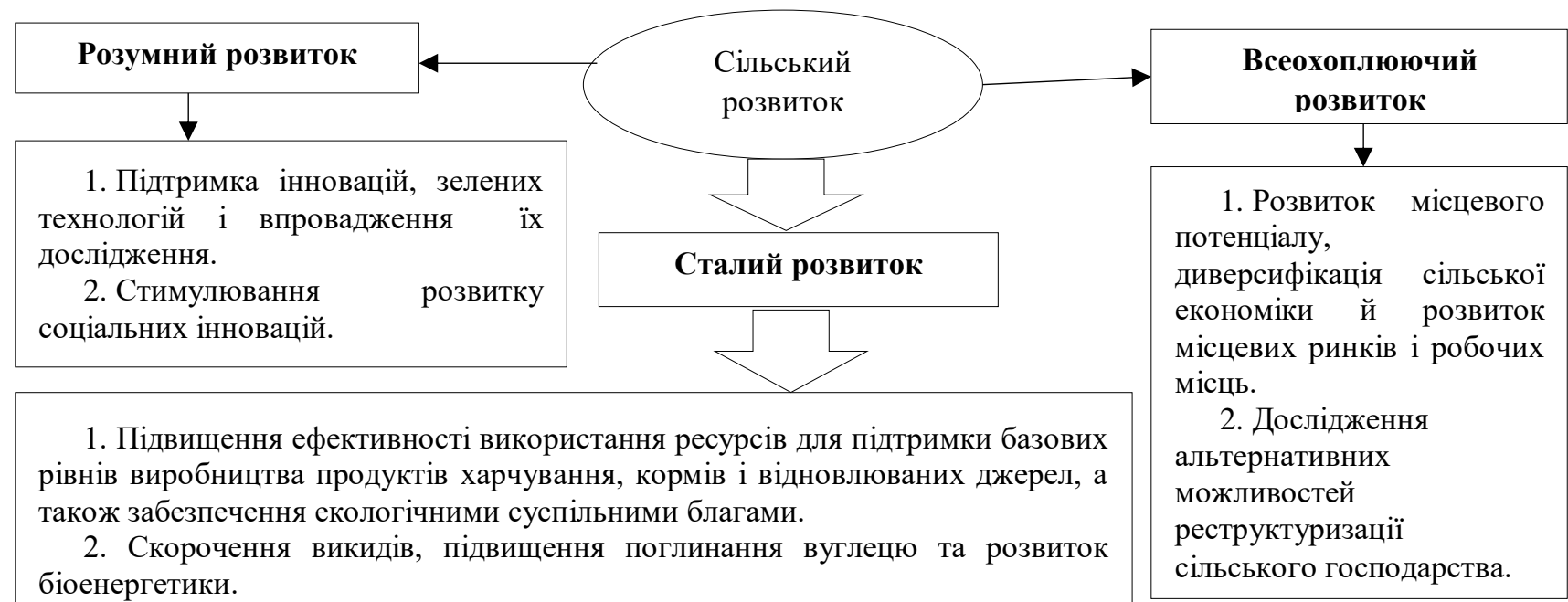

3. Забезпечення сталого управління земельними ресурсами й боротьба 3 втратою біорізноманіття.

\section{Рис. 2. Сільський розвиток у контексті Стратегії «Свропа 2020»} Джерело: [1, с. 26]

Такий підхід став можливий завдяки багатьом рокам розвитку ринкової економіки, насичення ринку, еволюційного відбору кращих компаній та реалізації через економічний потенціал своїх країн. Вигоди від євроінтеграції полягають, насамперед, у нівелюванні сучасних адміністративних бар'єрів між країнами, які стоять на перешкоді активізації економічної співпраці, перетоку товарів, послуг, капіталу, робочої сили тощо [4, с. 95]. Це не означає, що ці бар'єри блокують окремі потоки повністю, але вони суттєво їх ускладнюють $і$ знижують їхні обсяги, які потенційно можуть бути значно вищими.

Україна володіє значним потенціалом розвитку, що найперше стосується сільських територій. Водночас, наявність неабияких проблем у багатьох сферах господарювання не дає можливості його повноцінного використання. Сучасний розвиток сільських територій України відбувається в умовах загострення значної кількості проблем у різних сферах життєдіяльності. Як наслідок, із кожним роком дедалі більше зростає значимість заходів, спрямованих на покращення соціально-економічного стану вітчизняного села. Особлива роль у цьому контексті відводиться політиці європейської інтеграції України і iі наближення до стандартів $\mathrm{CC}$ за індикаторами розвитку сільських територій [20].

3 погляду євроінтеграційних перспектив розвитку українського села доцільно також розглядати функціонування інституційної пастки «віртуалізації євроінтеграційних зусиль», яка бере свій початок у самокоординуючому механізмі взаємодії владних інститутів, політичних партій, бізнесу й суспільства, за якого реальні інтереси одних можуть взаємоузгоджуватись із життєвими потребами інших лише у площині віртуальної євроінтеграційної активності. Тобто, реальна європейська інтеграція гальмується «інституційною імітацією» 3 боку окремих лобістських груп, зокрема представлених в органах державної влади, які прагнуть зберегти свій вплив через сформовані квазіефективні політичні інститути, блокуючи впровадження в Україні 
інституційних норм СС [3, с. 117], оскільки це загрожує їхньому існуванню та діяльності у звичному сьогодні форматі. Така ситуація перешкоджає реалізації євроінтеграційного курсу нашої держави, унеможливлює ефективний i багатофункціональний розвиток іiі сільських територій на основі зниження рівня адміністративних бар'єрів і проявів корупції, підвищення якості інформаційно-аналітичного забезпечення сільської економіки, розвитку інститутів громадянського суспільства.

Перспективи розвитку українського села й забезпечення рівноваги його економіки істотно залежать від державного регулювання. Значним ментальнопсихологічним бар'єром, який перешкоджає утвердженню модернізаційної парадигми розвитку сільських територій України в умовах європейської інтеграції, виступає зневіра селян у можливості змін у власній державі. Важливими напрямками Політики розвитку сільських територій в Україні, окрім європейських принципів, повинні стати й інші дієві заходи (рис. 3).

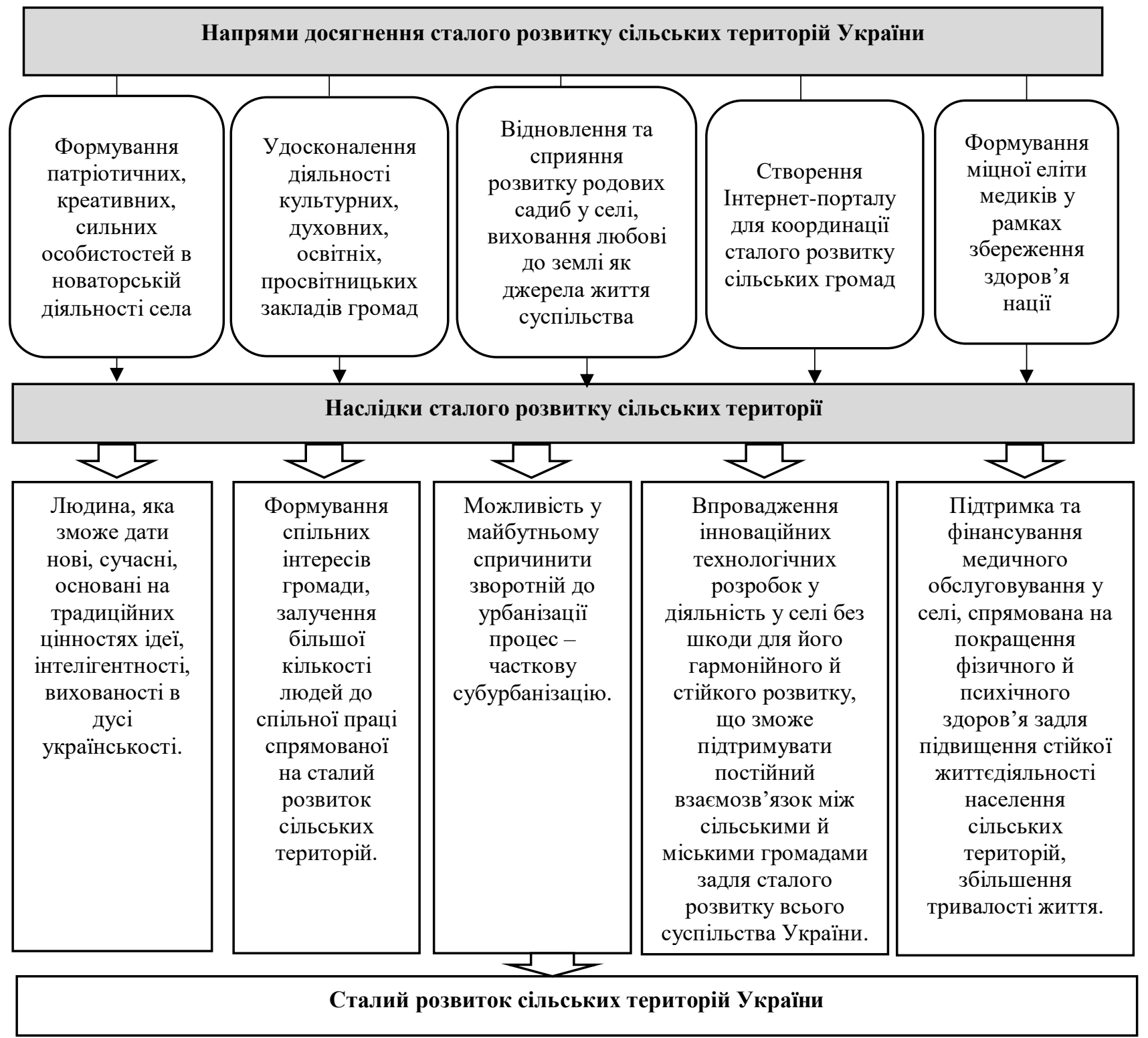

Рис. 3. Цілі розвитку сільських територій України на засадах сталості Джерело: [1, с. 42-45] 
Потрібно зазначити, що ми поділяємо думку Калетніка Г.М. [11, с. 518], який визначає необхідність державної підтримки формування, нагромадження та використання людського капіталу села. Управлінським документом у цій ситуації повинна стати концепція людського розвитку - однієї із основних складових політики сільського розвитку. За змістом ця концепція повинна містити конкретні завдання, які стосуються збереження наявного людського капіталу, удосконалення його структури, нормативно-правове забезпечення розвитку людського капіталу й інституційне забезпечення розвитку сільської економіки [12, с. 56; 13, с. 74]. Не менш значимою, 3 погляду забезпечення сталого розвитку сільських територій, $є$ реалізація навчальних програм щодо пошуку альтернативних видів економічної діяльності у селі. Для цього необхідно більш активно залучати заклади вищої освіти, консалтингові компанії та дорадницькі служби до підготовки фахівців сфери послуг, туризму, транскордонної співпраці, менеджменту й маркетингу, орієнтованих на роботу в сільській місцевості, створенню тут інноваційних виробництв, підприємств із іноземним капіталом тощо [18].

Кожний мешканець села чи міста має право на сучасну медицину й освіту, доступні та якісні адміністративні, комунальні, соціальні послуги, гарні дороги, чисті й освітлені вулиці. Але люди можуть впливати на якість цих послуг деякою мірою лише тоді, коли відповідальні за їхнє надання знаходяться близько. Найближчою до людей владою є органи місцевого самоврядування: сільські, селищні міські ради та їхні виконкоми. Отже, саме вони повинні мати широкі повноваження й достатньо коштів, щоб бути спроможними вирішувати усі проблеми населення і нести за це відповідальність [8].

У зв’язку з цим, в Україні відбувається процес децентралізації - передача повноважень і фінансів від державної влади якнайближче до людей - органам місцевого самоврядування [8]. У табл. 1 наведено інформацію щодо утворення ОТГ в Україні.

12 червня 2020 року Кабінет Міністрів України прийняв розпорядження щодо визначення адміністративних центрів і затвердження територій громад областей. У результаті в країні створено 1469 територіальних громад (зокрема, 31 територіальна громада на непідконтрольній території у межах Донецької та Луганської областей).

Державна політика України у сфері місцевого самоврядування спрямована на інтереси жителів територіальних громад i передбачає децентралізацію влади $[2$, с. $155 ; 6$. с. 12]. В основу цієї політики закладено положення Європейської хартії місцевого самоврядування та найкращі світові стандарти суспільних відносин у цій сфері. Законодавче підгрунтя, для докорінної зміни системи влади і ії територіальної основи, на всіх рівнях почало формуватися у 2014 році.

У квітні 2014 року Уряд схвалив основний концептуальний документ Концепцію реформування місцевого самоврядування та територіальної організації влади. Після цього був затверджений План заходів щодо іiі реалізації, які дали старт реформі. Для реалізації положень Концепції та завдань 
Плану заходів, необхідно було: по-перше, внести відповідні зміни до Конституції України, по-друге, сформувати пакет нового законодавства [8].

Табличя 1

Утворення ОТГ в Україні станом на початок 2021 p.

\begin{tabular}{|c|c|c|c|c|}
\hline Назва області & $\begin{array}{c}\text { Площа області, } \\
\text { км }^{2}\end{array}$ & $\begin{array}{c}\text { Кількість } \\
\text { населення, осіб }\end{array}$ & $\begin{array}{c}\text { Кількість } \\
\text { громад, од. }\end{array}$ & $\begin{array}{c}\text { Кількість } \\
\text { районів, од. }\end{array}$ \\
\hline Вінницька & 26513 & 1545416 & 63 & 6 \\
\hline Волинська & 20144 & 1031421 & 54 & 4 \\
\hline Дніпропетровська & 31914 & 3176978 & 86 & 7 \\
\hline Донецька & 26517 & 1843578 & 46 & 5 \\
\hline Житомирська & 29832 & 1208212 & 66 & 4 \\
\hline Закарпатська & 12777 & 1253791 & 64 & 6 \\
\hline Запорізька & 27180 & 1682534 & 67 & 5 \\
\hline Івано-Франківська & 13900 & 1368097 & 62 & 6 \\
\hline Київська & 28131 & 1781044 & 69 & 7 \\
\hline Кіровоградська & 24588 & 933209 & 49 & 4 \\
\hline Луганська & 26684 & 661028 & 26 & 4 \\
\hline Львівська & 21833 & 2512084 & 73 & 7 \\
\hline Миколаївська & 24598 & 1119862 & 52 & 4 \\
\hline Одеська & 33310 & 2377191 & 91 & 7 \\
\hline Полтавська & 28748 & 1386978 & 60 & 4 \\
\hline Рівненська & 20047 & 1152961 & 64 & 4 \\
\hline Сумська & 23834 & 1068247 & 51 & \\
\hline Тернопільська & 13823 & 1036590 & 55 & 3 \\
\hline Харківська & 31415 & 2654375 & 56 & 7 \\
\hline Херсонська & 28461 & 1027913 & 49 & 5 \\
\hline Хмельницька & 20645 & 1254702 & 60 & 3 \\
\hline Черкаська & 20900 & 1192137 & 66 & 4 \\
\hline Чернівецька & 8097 & 901632 & 52 & 3 \\
\hline Чернігівська & 31865 & 991294 & 57 & 5 \\
\hline Загалом & 575756 & 35161274 & 1438 & 119 \\
\hline
\end{tabular}

Джерело: [8]

Зміни до Конституції, перш за все, повинні були вирішити питання утворення виконавчих органів обласних і районних рад, реорганізації місцевих державних адміністрацій в органи контрольно-наглядового типу, дати чітке визначення адміністративно-територіальної одиниці - громади.

Зусиллями вітчизняних фахівців, практиків, науковців, експертів проєкт змін до Конституції був розроблений та переданий на широке публічне обговорення. Запропоновані зміни підтримало суспільство та високо оцінила Венеційська Комісія [8]. Аналіз досвіду реалізованих проєктів економічного розвитку сільських територій у розвинених країнах Свропи дозволяє виділити основні акценти, які необхідно використовувати під час розробки напрямів сільського розвитку в Україні (табл. 2).

Для сільських територій України активізація диверсифікації видів економічної діяльності є єдиним шляхом забезпечення сільського населення джерелами доходів і стимулом до подальшого проживання у них. Крім того, розвиток сільських територій потребує залучення значних інвестицій. Інвестиції у сільське господарство сприяють розвитку економіки, вирішенню соціально-економічних проблем і зміцненню продовольчої безпеки держави. Європейські країни $є$ основним джерелом прямих іноземних інвестицій, і великі європейські й американські аграрні компанії планують значно збільшити свої 
інвестиції у найближчі роки, незалежно від політичної невизначеності в Україні.

Табличя 2

Основні напрями сільського розвитку в Україні в умовах свроінтеграції

\begin{tabular}{|c|c|c|}
\hline № П/П & Назва & Характеристика \\
\hline 1 & Комплексність & $\begin{array}{l}\text { У проєктах економічного розвитку розглядати всі можливі види } \\
\text { господарської діяльності, здійснення яких може підвищити дохід } \\
\text { сільського населення. }\end{array}$ \\
\hline 2 & Відкритість & $\begin{array}{l}\text { Під час розробки проєктів необхідно використовувати методи } \\
\text { інтерактивного планування за участю населення через обговорення в } \\
\text { засобах масової інформації, на сільських зборах, «круглих столах». }\end{array}$ \\
\hline 3 & $\begin{array}{c}\text { Активна участь } \\
\text { місцевого населення }\end{array}$ & $\begin{array}{l}\text { У процесі розробки й реалізації проєкту повною мірою } \\
\text { використовуються знання, досвід й уявлення населення, враховуються } \\
\text { особливості економічної та соціальної поведінки різних соціальних груп, } \\
\text { забезпечується збалансованість їхніх інтересів. }\end{array}$ \\
\hline 4 & $\begin{array}{c}\text { Використання місиевих } \\
\text { ресурсів }\end{array}$ & $\begin{array}{l}\text { Мобілізація місцевих фінансових, матеріально-технічних, трудових } \\
\text { ресурсів, що має першочергове значення для створення стійких } \\
\text { механізмів забезпечення зайнятості та доходів. }\end{array}$ \\
\hline 5 & $\begin{array}{l}\text { Інституиіоналізація } \\
\text { проєктних рішень }\end{array}$ & $\begin{array}{l}\text { Передача функцій із реалізації проєкту й управління місцевим } \\
\text { адміністраціям. }\end{array}$ \\
\hline
\end{tabular}

Джерело: [4, с. 95]

У табл. 3 наведена інформація щодо обсягу прямих іноземних інвестицій в Україні з 2010 р. по 2020 р.

Табличя 3

Прямі іноземні інвестиції в Україні у 2010-2020 рр., млн дол. США

\begin{tabular}{|c|c|c|c|c|c|c|}
\hline Роки & В Україну & $\begin{array}{c}\text { Абсолютний } \\
\text { приріст } \\
\text { (поточний } \\
\text { рік (+/-) до } \\
\text { попереднього }\end{array}$ & 3 України & $\begin{array}{c}\text { Абсолютний } \\
\text { приріст } \\
\text { (поточний } \\
\text { рік (+/-) до } \\
\text { попереднього }\end{array}$ & $\begin{array}{c}\text { Відносний } \\
\text { приріст } \\
\text { (поточний } \\
\text { рік / до } \\
\text { попереднього }\end{array}$ \\
\hline 2010 & 6495 & 1679 & 736 & 574 & 5759 & $23,7 \%$ \\
\hline 2011 & 7207 & 712 & 192 & -544 & 7015 & $21,8 \%$ \\
\hline 2012 & 8401 & 1194 & 1206 & 1014 & 7195 & $2,6 \%$ \\
\hline 2013 & 4499 & -3902 & 420 & -786 & 4079 & $-43,3 \%$ \\
\hline 2014 & 410 & -4089 & 111 & -309 & 299 & $-92,7 \%$ \\
\hline 2015 & 2961 & 2551 & -51 & -162 & 3012 & $907,4 \%$ \\
\hline 2016 & 3284 & 323 & 16 & 67 & 3268 & $8,5 \%$ \\
\hline 2017 & 2202 & -1082 & 8 & -8 & 2194 & $-32,9 \%$ \\
\hline 2018 & 2355 & 153 & -5 & -13 & 2360 & $7,6 \%$ \\
\hline 2019 & 3070 & 715 & 648 & 653 & 2422 & $2,6 \%$ \\
\hline 2020 & -343 & -3413 & 56 & -592 & -399 & $-116,5 \%$ \\
\hline
\end{tabular}

Джерело: [15]

Для успішного виконання завдань євроінтеграції аграрний сектор економіки України має достатньо передумов, а саме: багатий природноресурсний та експортний потенціал, людський капітал, поступово зростаючу інвестиційну привабливість, збережений уклад сільського життя та багатовікові традиції ведення сільського господарства. У цьому контексті дослідження та наукове осмислення досвіду формування європейської аграрної моделі сприятимуть проведенню структурних реформ у галузі сільського господарства й підвищенню рівня конкурентоспроможності агропродовольчої продукції на європейському й світовому ринках [20]. 
Адаптація стандартів аграрної політики з прозорими й передбачуваними регуляторними правилами сприятиме покращенню інвестиційного клімату й інвестиційної привабливості аграрного сектора економіки для європейських партнерів.

Значний потенціал агропромислового комплексу пов'язаний також із поєднанням агровиробників України та СС у виробничих ланцюгах і каналах збуту. Це дозволить підвищити продуктивність агропромислового комплексу за допомогою передачі передових технологій та практик $Є С$, збільшенню масштабів діяльності у виробництво й переробку сільськогосподарської продукції, покращенню умов доступу на світові ринки.

Взагалі, сталий економічний розвиток $є$ об'єктивною необхідністю подальшого зростання виробничих відносин у світі. Як відомо, основою для визначення цілей сталого розвитку сільського господарства стала концепція багатофункціональної його ролі, згідно з якою сільське господарство виконує багато функцій у суспільстві - виробництво безпечного й екологічного продовольства; допомога сталому розвитку сільської місцевості, насамперед, захист і поліпшення стану навколишнього середовища. Ця концепція прийнята на конференції ФАО (у 2003 р. членом цієї міжнародної продовольчої та сільськогосподарської організації стала Україна) у Нідерландах (м. Маастрихт) у вересні 1999 р. [12, с. 56].

В умовах кризової ситуації у системі європейської й світової безпеки, а також кризи європростору, дослідження механізмів розвитку саме аграрного сектора національної економіки в сучасних реаліях інтеграційних процесів $\epsilon$ вкрай актуальними. Одним із таких сучасних механізмів $€$ функціонування зони вільної торгівлі між Україною та ЄС. Науковий інтерес викликають сучасний стан сільського господарства та його «реакція» на відкриття ринків СС для українських сільськогосподарських товарів, а також перспективи подальшої інтеграції [21, с. 44].

Такий розвиток передбачає покращення соціально-економічних умов у сільській місцевості через поліпшення можливостей для працевлаштування, підвищення доходів домогосподарств і мобільності їх членів [2, с. 154]. Сільський розвиток на засадах сталості $є$ обгрунтованим процесом послідовних економічних, соціальних, політичних, культурних й екологічних змін, спрямованих на поліпшення якості життя, який повинен задовольняти потреби сільського населення та не створювати загроз для майбутніх поколінь [3, с. 116].

На основі вивченого досвіду ми вважаємо, що Україні доцільно: розробити комплекс регіональних програм розвитку сільських територій 3 урахуванням природно-географічних особливостей та існуючого стану розвитку сільських територій; зосередити державну політику на розвитку людського капіталу як основи функціонування села; забезпечити відповідну інституційну структуру, здатну здійснювати безперервний моніторинг стану сільських територій та сприяти обміну досвідом із країнами Європи й іншими розвиненими країнами світу.

Реалізація зазначених заходів i подальші наукові розробки щодо удосконалення політики розвитку сільських територій в Україні $є$ запорукою 
ефективного економічного зростання аграрного сектору й економіки України загалом.

Висновки. Розвиток сільських територій України виступає одним із пріоритетів державної політики України, спрямованої на вирішення економічних, соціальних, побутових, екологічних, гуманітарних, демографічних та інших проблем мешканців українського села, які становлять значну, а в деяких регіонах - переважаючу, частину населення держави.

Сучасна фінансова політика розвитку сільських територій повинна бути реалізована за допомогою кооперації ресурсів держави, бізнесу (інвесторів) і населення, та спрямовуватись на стимулювання підприємницької активності, створення нових робочих місць, формування сприятливого інвестиційного клімату тощо, що в кінцевому результаті дозволить забезпечити самодостатній розвиток сільських територіальних громад.

Реалізація європейської політики розвитку сільських територій грунтується на взаємодоповнюваності повноважень державних органів і всіх складових розвиненої мережі фінансових i громадських інституцій, професійних, наукових і дорадчих асоціацій, які беруть участь у забезпеченні розумного, сталого й всеохоплюючого розвитку сільських територій.

\section{Список використаних джерел}

1. Борщевський В.В., Притула Х.М., Крупін В.С., Куліш I.M., Злидник Ю.Р. Розвиток сільських територій в системі євроінтеграційних пріоритетів України: монографія. Львів: Інститут регіональних досліджень. НАН України. 2012. 216 с.

2. Важинський Ф.А. Сутність i значення соціально-економічного розвитку сільських територій. Науковий вісник НЛТУ Украйни. 2010. Вип. 20/5. C. $152-157$.

3. Венгерська Н.С. Сільський розвиток України в умовах євроінтеграції: проблеми та перспективи. Економічний вісник. 2015. № 4. С. 113-118.

4. Венгерська Н.С. Напрями забезпечення регіонального сільського розвитку України в умовах євроінтеграції. Науковий вісник Херсонського державного університету. Серія «Економічні науки». 2015. Вип. 15. Ч. 5. C. 94-97.

5. Гончарук I.В., Браніцький Ю.Ю., Томашук І.В. Основні аспекти ефективного формування i використання ресурсного потенціалу $\mathrm{y}$ сільськогосподарських підприємствах (на прикладі УладовоЛюлинецької ДСС ІБК НААН України). Економіка, фінанси, менеджмент: актуальні питання науки і практики. 2017. № 10 (26). С. 54-68.

6. Гончарук I.B., Томашук I.B. Державне регулювання розвитку ресурсного потенціалу сільських територій: загальні аспекти. Економіка, фінанси, менеджмент: актуальні питання науки і практики. 2018. № 4 (32). C. 19-30.

7. Гилка М.Д. Розвиток сільських територій України у контексті євроінтеграційних процесів. Глобальні та національні проблеми економіки. 2015. Вип. 4. С. 124-129.

8. Децентралізація дає можливості. URL: https://decentralization. 
gov.ua/about (дата звернення: 22.01.2021).

9. Офіційний сайт Державної служби статистики України. URL: http://www.ukrstat.gov.ua (дата звернення: 16.01.2021).

10. ЄС-Україна: поглиблена та всеохоплююча зона вільної торгівлі. URL: https://eeas.europa.eu/archives/delegations/ukraine/documents/virtual_library/dcfta_g uidebook_web.pdf (дата звернення: 18.07.2021).

11. Kaletnik G., Honcharuk I., Okhota Yu. The waste-free production development for the energy autonomy formation of Ukrainian agricultural enterprises. Journal of Environmental Management and Tourism. 2020. Vol. XI. № 3 (43). P. 513-522. DOI: https://doi.org/10.14505//jemt.v11.3(43).02.

12. Ковальчук С.Я. Вплив глобалізаційних процесів на розвиток сільських територій у контексті селозберігаючої моделі аграрного підприємництва. Економіка і суспільство. 2017. Вип. 8. С. 52-58.

13. Mazur K.V., Tomashuk I.V. Governance and regulation as an indispensable condition for developing the potential of rural areas. Baltic Journal of Economic Studies. 2019. № 5. Vol. 5. P. 67-78. DOI: https://doi.org/10.30525/2256-0742/20195-5-67-78.

14. Офіційний сайт Національного наукового центру «Інститут аграрної економіки». URL: http://iae.org.ua/presscentre/archnews/2912-instytut-ahrarnoyiekonomiky-prezentuv av-stratehichni-napryamy-staloho-rozvytku-silskykh-terytoriyna-period-do-2030-ro ku.html (дата звернення: 11.04.2021).

15. Офіційний сайт Міністерства фінансів України. URL: https://index.minfin.com.ua/economy/fdi/2020/ (дата звернення: 14.05.2021).

16. Піняга Н.О. Ресурсний потенціал сільськогосподарських підприємств у контексті сталого їх розвитку. Інноваиійна економіка. 2013. № 6 (44). С. 103106.

17. Rural development 2014-2020. European Commission. URL: http://ec.europa.eu. (дата звернення: 24.06.2021).

18. The Cork Declaration - A living countryside. URL: http://ec.europa.eu/agriculture/rur/cork_en.htm (дата звернення: 27.05.2021).

19. Tomashuk I.V. Problems and prospects of management development of rural territories. Baltic Journal of Economic Studies. 2017. Vol. 3. № 5. P. 214-220.

20. Чеканська Л.А. Свроінтеграційні процеси України та їх вплив на інвестування в АПК. Ефективна економіка. 2014. № 10. URL: http://www.economy.nayka.com.ua/?op=1\&z=3459 (дата звернення: 21.04.2021).

21. Яценко О.М., Невзгляд Н.Г., Невзгляд. А.Г. Розвиток експортного потенціалу аграрного сектора економіки України в умовах глобалізації. Зовнішня торгівля: економіка, фінанси, право. Серія: економічні науки. 2015. № 3 (80). C. 39-49.

\section{References}

1. Borshchevskyi, V.V. (2012). Rozvytok silskykh terytorii $v$ systemi yevrointehratsiinykh priorytetiv Ukrainy [Development of rural areas in the system of European integration priorities of Ukraine]. Lviv: Instytut rehionalnykh doslidzhen NAN Ukrainy [in Ukrainian].

2. Vazhynskyi, F.A. (2010). Sutnist i znachennia sotsialno-ekonomichnoho 
rozvytku silskykh terytorii [The essence and significance of socio-economic development of rural areas]. Naukovyi visnyk NLTU Ukrainy - Scientific Bulletin of the National Forestry University of Ukraine, 20/5, 152-157 [in Ukrainian].

3. Venherska, N.S. (2015). Silskyi rozvytok Ukrainy v umovakh yevrointehratsii: problemy ta perspektyvy [Rural development of Ukraine in the context of European integration: problems and prospects]. Ekonomichnyi visnyk Economic Bulletin, 4, 113-18 [in Ukrainian].

4. Venherska, N.S. (2015). Napriamy zabezpechennia rehionalnoho silskoho rozvytku Ukrainy v umovakh yevrointehratsii [Directions for ensuring regional rural development of Ukraine in the context of European integration]. Naukovyi visnyk Khersonskoho derzhavnoho universytetu. Seriia «Ekonomichni nauky»-Scientific Bulletin of Kherson State University. Series «Economic sciences», 15, 5, $94-97$ [in Ukrainian].

5. Honcharuk, I.V., \& Branitskyi, Yu.Yu., \& Tomashuk, I.V. (2017). Osnovni aspekty efektyvnoho formuvannia i vykorystannia resursnoho potentsialu $u$ silskohospodarskykh pidpryiemstvakh (na prykladi Uladovo-Liulynetskoi DSS IBK NAAN Ukrainy) [The main aspects of effective formation and use of resource potential in agricultural enterprises (on the example of Vladovo-Lyulinetskaya Research and Breeding Station of the Institute of Bioenergy Cultures of the National Academy of Agrarian Sciences of Ukraine)]. Ekonomika, finansy, menedzhment: aktualni pytannia nauky $i$ praktyky - Economics, finance, management: topical issues of science and practical activity, 10 (26), 54-68 [in Ukrainian].

6. Honcharuk, I.V., \& Tomashuk, I.V. (2018). Derzhavne rehuliuvannia rozvytku resursnoho potentsialu silskykh terytorii: zahalni aspekty [State regulation of resource potential development in rural areas: general aspects]. Ekonomika, finansy, menedzhment: aktualni pytannia nauky i praktyky - Economics, finance, management: topical issues of science and practical activity, 4 (32), 19-30 [in Ukrainian].

7. Hylka, M.D. (2015). Rozvytok silskykh terytorii Ukrainy u konteksti yevrointehratsiinykh protsesiv [Development of rural areas of Ukraine in the context of European integration processes]. Hlobalni ta natsionalni problemy ekonomiky Global and national economic problems, 4, 124-129 [in Ukrainian].

8. Detsentralizatsiia daie mozhlyvosti [Decentralization provides opportunities]. decentralization.gov.ua. Retrieved from: https://decentralization.gov.ua/about [in Ukrainian].

9. Derzhavna sluzhba statystyky Ukrainy [State Statistics Service of Ukraine]. ukrstat.gov. Retrieved from: http://www.ukrstat.gov.ua [in Ukrainian].

10. YeS-Ukraina: pohlyblena ta vseokhopliuiucha zona vilnoi torhivli [EUUkraine: a deep and comprehensive free trade area]. eeas.europa. Retrieved from: https://eeas.europa.eu/archives/delegations/ukraine/documents/virtual_library/dcfta_g uidebook_web.pdf [in Ukrainian].

11. Kaletnik, G., \& Honcharuk, I., \& Okhota, Yu. (2020). The waste-free production development for the energy autonomy formation of ukrainian agricultural enterprises. Journal of Environmental Management and Tourism, XI, 3 (43), 513-522. DOI: https://doi.org/10.14505//jemt.v11.3(43).02 [in English]. 
12. Kovalchuk, S.Ya. (2017). Vplyv hlobalizatsiinykh protsesiv na rozvytok silskykh terytorii u konteksti selozberihaiuchoi modeli ahrarnoho pidpryiemnytstva [The impact of globalization processes on the development of rural areas in the context of the village-preserving model of agricultural entrepreneurship]. Ekonomika $i$ suspilstvo - Economy and society, 8, 52-58 [in Ukrainian].

13. Mazur, K.V., \& Tomashuk, I.V. (2019). Governance and regulation as an indispensable condition for developing the potential of rural areas. Baltic Journal of Economic Studies, 5, 5, 67-78. DOI: https://doi.org/10.30525/2256-0742/2019-5-567-78 [in English].

14. Natsionalnyi naukovyi tsentr Instytutu ahrarnoi ekonomiky [National Research Center of the Institute of Agrarian Economics]. iae.org.ua. Retrieved from: http://iae.org.ua/presscentre/archnews/2912-instytut-ahrarnoyi-ekonomiky-prezentuv av-stratehichni-napryamy-staloho-rozvytku-silskykh-terytoriy-na-period-do-2030-ro ku.html [in Ukrainian].

15. Ministerstvo finansiv Ukrainy [Ministry of Finance of Ukraine]. index.minfin.com.ua. Retrieved from: https://index.minfin.com.ua/economy/fdi/2020/ [in Ukrainian].

16. Piniaha, N.O. (2013). Resursnyi potentsial silskohospodarskykh pidpryiemstv u konteksti staloho yikh rozvytku [Resource potential of agricultural enterprises in the context of their sustainable development]. Innovatsiina ekonomika - Innovative economy, 6 (44), 103-106 [in Ukrainian].

17. Rural development 2014-2020. European Commission. ec.europa.eu. Retrieved from: http://ec.europa.eu [in English].

18. The Cork Declaration - A living countryside. ec.europa.eu. Retrieved from: http://ec.europa.eu/agriculture/rur/cork_en.htm [in English].

19. Tomashuk, I.V. (2017). Problems and prospects of management development of rural territories. Baltic Journal of Economic Studies, 3, 5, 214-220 [in English].

20. Chekanska, L.A. (2014). Yevrointehratsiini protsesy Ukrainy ta yikh vplyv na investuvannia $\mathrm{v}$ APK [European integration processes of Ukraine and their impact on investment in agribusiness]. Efektyvna ekonomika - Efficient economy, 10. economy.nayka.com.ua. Retrieved from: http://www.economy.nayka.com. ua/?op=1\&z=3459 [in Ukrainian].

21. Yatsenko, O.M., \& Nevzghliad, N.H., \& Nevzghliad, A.H. (2015). Rozvytok eksportnoho potentsialu ahrarnoho sektora ekonomiky Ukrainy v umovakh hlobalizatsii [Development of export potential of the agricultural sector of Ukraine's economy in the conditions of globalization]. Zovnishnia torhivlia: ekonomika, finansy, pravo. Seriia: ekonomichni nauky - Foreign trade: economics, finance, law. Series: economic sciences, 3 (80), 39-49 [in Ukrainian].

\section{Відомості про авторів}

ТОМАШУК Інна Вікторівна - доктор філософії з економіки, старший викладач кафедри економіки та підприємницької діяльності, Вінницький національний аграрний університет (21008, м. Вінниця, вул. Сонячна, 3, e-mail: tomashuk.inna@ukr.net).

БАЛДИНЮК Василь Михайлович - кандидат наук 3 державного 
управління, доцент кафедри адміністративного менеджменту та альтернативних джерел енергії, Вінницький національний аграрний університет (21008, м. Вінниця, вул. Сонячна, 3, e-mail: baldynyuk@gmail.com).

ТОМАШУК Іван Олегович - аспірант Національного наукового центру «Інститут аграрної економіки» (03127, м. Київ, вул. Героїв Оборони, 10, e-mail: pd@iae.org.ua).

TOMASHUK Inna - PhD of Economics, Senior Lecturer of the Department of Economics and Entrepreneurship, Vinnytsia National Agrarian University (21008, Vinnytsia, 3, Soniachna Str., e-mail: tomashuk.inna@ukr.net).

BALDYNYUK Vasyl - Candidate of Science in Public Administration, Associate Professor of the Department of Administrative Management and Alternative Energy Sources, Vinnytsia National Agrarian University (21008, Vinnytsia, 3, Soniachna Str., e-mail: baldynyuk@gmail.com).

TOMASHUK Ivan - postgraduate student of the National Research Center «Institute of Agrarian Economics», 03127, Kyiv, 10, Heroiv Oborony Str., e-mail: pd@iae.org.ua).

ТОМАШУК Инна Викторовна - доктор философии по экономике, старший преподаватель кафедры экономики и предпринимательской деятельности, Винницкий национальный аграрный университет (21008, г. Винница, ул. Солнечная, 3, e-mail: tomashuk.inna@ukr.net).

БАЛДИНЮК Василий Михайлович - кандидат наук по государственному управлению, доцент кафедры административного менеджмента и альтернативных источников энергии, Винницкий национальный аграрный университет (21008, г. Винница, ул. Солнечная, 3, e-mail: baldynyuk@gmail.com).

ТОМАШУК Иван Олегович - аспирант Национального научного центра «Институт аграрной экономики» $(03127$, г. Киев, ул. Героев Обороны, 10, e-mail: pd@iae.org.ua).

УДК 339.5(477+4-6€C)

DOI: 10.37128/2411-4413-2021-4-9

АНАЛІЗ ПРОБЛЕМ І
ПЕРСПЕКТИВ
ЗОВНІШНЬОЇ
ТОРГІВЛІ УКРАЇНИ
3 КРАЇНАМИ ЄС

ХАЕЦЬКА О.П., кандидат економічних наук, доцент, завідувачка кафедри економіки та підприємницької діяльності, Вінницький національний аграрний університет (м. Вінниця)

У статті проаналізовано особливості зовнішньої торгівлі Украӥни з іншими краӥнами, зокрема з краӥнами Свропейського Союзу. Розвиток зовнішньої торгівлі $\epsilon$ важливим для аналізу економічного стану краӥни, відображає ставлення країн світу до вітчизняної продукції. Визначено траєкторію розвитку зовнішньої торгівлі, щзо формує резерви підвищення рівня міжнародних торговельних відносин $i$ підвищує конкурентоспроможність української продукиії.

Наведено динаміку змін у географічній та товарній структурі міжнародної торгівлі 